\title{
PENGARUH METODE THINK TALK WRITE (TTW) TERHADAP KEMAMPUAN PEMECAHAN MASALAH MATEMATIKA ANAK TUNARUNGU KELAS XI SLB NEGERI SURAKARTA TAHUN AJARAN 2019/2020
}

\author{
Darah Sri Rohmahwati \\ Pendidikan Luar Biasa, Fakultas Ilmu Pendidikan, UNS Surakarta \\ darahrohmahwati@gmail.com \\ Kumala Sari, Anggrellanggi \\ Pendidikan Luar Biasa, Fakultas Ilmu Pendidikan, UNS Surakarta \\ kumalasari@gmail.com, anggrellanggi@gmail.com
}

\begin{abstract}
Abstrak
Penelitian ini bertujuan untuk mengetahui pengaruh metode Think Talk Write (TTW) terhadap kemampuan pemecahan masalah matematika pada anak tunarungu kelas XI. Penelitian ini menggunakan pendekatan eksperimen dengan desain penelitian one group pretest-posttest design. Sampel yang digunakan sebanyak 8 orang siswa tunarungu dan menggunakan teknik pengambilan sampel nonprobability sampling dengan jenis sampling jenuh. Teknik pengumpulan data menggunakan soal tes objektif pilihan ganda dan soal uraian.Uji validitas instrumen menggunakan validitas isi dengan perhitungan Aiken's V. Uji reliabilitas instrumen menggunakan teknik penilaian konsistensi diantara para rater (interrater reliability). Teknik analisis data penelitian ini menggunakan Wilcoxon Sign Rank Test. Pada analisis data menggunakan analisis wilcoxon sign rank test diperoleh $\mathrm{Z}$ hitung $=-2.533$ dengan nilai Asymp. Sig. (2-tailed) atau $\mathrm{p}=0.011$ yang berada dibawah taraf signifikansi $(\alpha)$ yang ditentukan yaitu $0,05(5 \%)$. Pada penelitian ini dapat ditarik kesimpulan bahwa metode ThinkTalk Write (TTW) berpengaruh terhadap kemampuan pemecahan masalah matematika anak tunarungu kelas XI di SLB Negeri Surakarta tahun ajaran 2019/2020.
\end{abstract}

Kata Kunci: Think Talk Write, tunarungu, matematika

\begin{abstract}
This study aims to know the influence of the Think Talk Write (TTW) method toward mathematics problem-solving ability of deaf children of class XI.. This study used an experimental approach to the research design that is one group pretest-posttest design. The sample used in this study were 8 deaf and determined using a nonprobability sampling technique with a saturated sampling type. The data collection technique used a multiple-choice test and description questions. The instrument validity test used content validity with Aiken's V calculation. The instrument reliability test used a consistency assessment technique interrater reliability. The data analysis used the Wilcoxon Sign Rank Test. Analysis of the data in the Wilcoxon sign rank test obtained $\mathrm{Z}$ count $=-23333$ with Asymp values. Sig. (2-tailed) or $\mathrm{p}=0.011$ which is below the specified significance level $(\alpha)$ which is $0.05(5 \%)$. In this study, it can be concluded that the Think Talk Write (TTW) method influences mathematics problem-solving ability of deaf children of class XI SLB Negeri Surakarta in academic year 2019/2020.
\end{abstract}

Keywords: Think Talk Write, deaf, mathematics 


\section{PENDAHULUAN}

Anak tunarungu memiliki hambatan dalam proses pembelajaran, khususnya dalam memecahkan masalah matematika, namun anak tunarungu juga berhak mendapatkan pendidikan yang layak dan sesuai dengan kebutuhnnya. Anak tunarungu memiliki masalah dalam perkembangan bahasa dan berbicara, sehingga potensi visualnya perlu lebih dioptimalkan sebagai kompensatoris. Adanya permasalahan bahasa menyebabkan anak tunarungu kesulitan dalam mengikuti salah satu mata pelajaran yaitu matematika. Matematika merupakan suatu ilmu pengetahuan yang mempelajari tentang bilangan dan tentang pemecahan masalah kaitannya dengan aktivitas sehari-hari. Menurut NCTM (dalam Syahlan, 2017: 358), salah satu yang menjadi fokus dalam kemampuan belajar matematika yaitu kemampuan dalam pemecahan masalah. Dalam hal ini mata pelajaran matematika merupakan mata pelajaran yang dapat menunjang mata pelajaran yang lain.

Berdasarkan observasi yang dilakukan oleh peneliti di SLB Negeri Surakarta, peneliti menemukan bahwa anak tunarungu kelas XI SLB dalam kegiatan pembelajaran mengalami masalah terkait dengan pemecahan masalah matematika. Pemecahan masalah matematika yang dimaksud di sini adalah anak kesulitan dalam menyelesaikan soal cerita matematika. Saat mengerjakan soal cerita matematika, anak tunarungu membutuhkan waktu yang lebih banyak dalam mengerjakan. Selain itu, anak tunarungu ketika mengerjakan sering salah dalam menjawab soal. Hal tersebut mempengaruhi prestasi belajar anak tunarungu di sekolah terutama dalam pelajaran matematika. Berkaitan dengan hal tersebut maka, anak tunarungu membutuhkan kegiatan pembelajaran menggunakan metode yang sesuai dengan karakteristiknya. karena anak tunarungu juga memiliki pemahaman konsep matematika yang rendah

Untuk mengatasi permasalahan tersebut peneliti mencoba untuk mengetahui pengaruh metode TTW terhadap kemampuan pemecahan masalah matematika anak tunarungu kelas XI SLB Negeri Surakarta tahun ajaran 2019/2020. Menurut Huda (2017: 218), Think Talk Write merupakan strategi yang menyediakan latihan berbahasa secara lisan dan menulis Bahasa tersebut dengan lancar. Pendapat lain menurut Shoimin (2014: 212), Think Talk Write merupakan suatu metode pembelajaran dimana untuk melatih keterampilan peserta didik dalam kegiatan menulis selain itu juga menekankan pentingnya peserta didik dalam mengkomunikasikan hasil dari pemikirannya. Sementara itu, telah terdapat penelitian yang menggunakan metode ini dalam meningkatkan hasil belajar matematika pada materi sistem persamaan linear dua variabel yang dilakukan oleh Mustika Fitri Larasati Sibuea pada tahun 2017. 
Berikut ini adalah komponen dari metode pembelajaran Think Talk Write (TTW) menurut (Shoimin, 2014; Huda, 2014): (1) Think (Berpikir), (2)Talk (Berbicara), (3) Write (Menulis). Metode TTW pernah diterapkan pada anak tunarungu dengan pelaksanaan yang dimulai dari tahap think melalui bahan bacaan, setelah tahap think dilanjutkan dengan tahap talk yaitu dengan melakukan diskusi, siswa melakukan komunikasi dengan menggunakan kata-kata dan bahasa yang mereka pahami. Dalam tahap ini diharapkan siswa mampu berinteraksi dengan teman-temannya sendiri. Tahap terakhir adalah write yaitu menuliskan hasil diskusi pada lembar kertas yang telah disediakan dimana kertas yang digunakan menggunakan kertas berwana sehingga dapat menarik siswa dalam kegiatan pembelajaran. (Dewayani, 2016). Kemajuan dari metode ini dapat dilihat dari keikutsertaan siswa dalam melakukan proses berpikir atau berdialog dengan dirinya sendiri setelah melakukan proses membaca. Selanjutnya, berbicara dan membagi ide (sharing) dengan temannya sebelum melakukan kegiatan menulis. Kegiatan ini akan efektif jika dilakukan dalam kelompok heterogen, sehingga dapat dibentuk kelompok dengan anggota disesuaikan dengan jumlah siswa dikelas tersebut.

\section{METODE}

Penelitian ini dilaksankan di SLB Negeri Surakarta yang berlokasi di Jalan Cocak X Sidorejo, Mangkubumen, Banjarsari, Surakarta, Jawa Tengah. Penelitian ini dilaksanakan pada bulan November sampai dengan bulan April 2020. Penelitian ini menggunakan penelitian eksperimen dengan jenis desain One-Group Pretest-Posttest Design. Sampel dalam penelitian ini adalah seluruh siswa-siswi tunarungu kelas XI di SLB Negeri Surakarta Tahun Ajaran 2019/2020 yang berjumlah 8 orang. teknik pengambilan sampel yang dilakukan menggunakan teknik sampling Non Probability sampling dengan jenis sampling jenuh. Teknik pengumpulan data yang digunakan berupa tes tertulis, yang dibagi menjadi duajenis bentuk tes yaitu tes objektif dan tes uraian. Teknik analisis data ynag digunakan menggunakan perhitungan Wilcoxon Sign Rank Test.

\section{PEMBAHASAN}

Pada saat pelaksanaan pretest atau tes kemampuan awal siswa, nilai siswa tergolong rendah yaitu dengan perolehan nilai rata-rata siswa sebesar 47.125 dan nilai terendah dari pretest yang telah dilakukan adalah sebesar 33.00 sedangkan, nilai tertinggi pada pretest yang telah dilaksanakan sebesar 63.00 berikut adalah awal nilai siswa yang disajikan dalam tabel 1 
Tabel 1. Data Nilai Awal Siswa

\begin{tabular}{|ccc|}
\hline No & $\begin{array}{c}\text { Nama/Inisial } \\
\text { Subjek }\end{array}$ & Nilai Pretest \\
\hline 1 & MYS & 60 \\
2 & FAK & 40 \\
3 & YFK & 55 \\
4 & IM & 63 \\
5 & DPK & 45 \\
6 & ISH & 33 \\
7 & YNC & 38 \\
8 & TP & 43 \\
\hline \multicolumn{2}{r}{ Rata-rata Nilai Pretest } \\
\hline
\end{tabular}

Setelah siswa diberikan perlakuan menggunakan metode TTW, terdapat kenaikan nilai dalam pelaksanakan post test yaitu rata-rata nilai siswa menjadi 67.75. Berikut adalah data nilai akhir siswa yang disajikan dalam tabel 2

Tabel 2. Data Nilai Akhir Siswa

\begin{tabular}{|ccc|}
\hline No & $\begin{array}{c}\text { Nama/Inisial } \\
\text { Subjek }\end{array}$ & Nilai Posttest \\
\hline 1 & MYS & 73 \\
2 & FAK & 65 \\
3 & YFK & 83 \\
4 & IM & 75 \\
5 & DPK & 70 \\
6 & ISH & 58 \\
7 & YNC & 53 \\
8 & TP & 65 \\
\hline \multicolumn{2}{r}{ Rata-rata Nilai Posttest } \\
\hline
\end{tabular}

Dapat diketahui bahwa siswa yang memiliki nilai tertinggi yaitu 83 dan siswa yang memiliki nilai terendah adalah 53, selain itu siswa yang mendapat nilai sama sebanyak dua orang yaitu 65 dan beberapa siswa mendapatkan nilai 73, 75, 70, 58. Berikut adalah perbandingan nilai siswa sebelum diberikan perlakuan dan setelah diberikan perlakuan menggunakan metode TTW yang disajikan dalam tabel 3 
Tabel 3 Perbandingan Nilai Pretest dan Posttest

\begin{tabular}{|ccc|}
\hline Nama/Inisial Subjek & $\begin{array}{c}\text { Nilai } \\
\text { Pretest }\end{array}$ & $\begin{array}{c}\text { Nilai } \\
\text { Postest }\end{array}$ \\
\hline MYS & 60 & 73 \\
FAK & 40 & 65 \\
YFK & 55 & 83 \\
IM & 63 & 75 \\
DPK & 45 & 70 \\
ISH & 33 & 58 \\
YNC & 38 & 53 \\
TP & 43 & 65 \\
\hline Nilai Rata-rata & 47.125 & 67.75 \\
\hline
\end{tabular}

Tabel di atas menunjukkan bahwa terdapat perbedaan nilai siswa sebelum diberikan perlakuan dan setelah diberikan perlakuan menggunakan metode TTW, dapat ditolak dan $\mathrm{Ha}_{\text {a diterima. Taraf }}$ signifikansi yang dimaksudkan disini adalah sebesar $5 \%$ yaitu besarnya nilai probabilitas 0,05 atau memiliki tingkat kepercayaan sebesar 95\%. Berikut adalah hasil analisis dari Wilcoxon Sign Rank Test menggunakan aplikasi SPSS versi 25, yang disajikan dalam bentuk tabel 4

Tabel 4 Hasil Analisis Wilcoxon Sign Rank Test

\begin{tabular}{|c|c|c|c|c|}
\hline \multicolumn{5}{|c|}{ Ranks } \\
\hline & & $\mathrm{N}$ & $\begin{array}{l}\text { Mean } \\
\text { Rank }\end{array}$ & $\begin{array}{c}\text { Sum } \\
\text { of Ranks }\end{array}$ \\
\hline \multirow[t]{4}{*}{$\begin{array}{l}\text { Postest - } \\
\text { Pretest }\end{array}$} & $\begin{array}{l}\text { Negative } \\
\text { Ranks }\end{array}$ & $0^{a}$ & .00 & .00 \\
\hline & $\begin{array}{l}\text { Positive } \\
\text { Ranks }\end{array}$ & $8 b$ & 4.50 & 36.00 \\
\hline & Ties & $0 \mathrm{C}$ & & \\
\hline & Total & 8 & & \\
\hline \multicolumn{5}{|c|}{$\begin{array}{l}\text { a. Postest }<\text { Pretest } \\
\text { b. Postest }>\text { Pretest } \\
\text { c. Postest }=\text { Pretest }\end{array}$} \\
\hline
\end{tabular}

Hasil analisis Wilcoxon Sign diketahui bahwa setiap subjek mengalami kenaikan nilai setelah diberikan perlakuan menggunakan metode TTW, sehingga nilai rata-rata pretest dan posttest mengalami kenaikan,. Pada penelitian ini menggunakan uji normalitas yaitu jika p atau Asymp. Sig. (2-tailed) melebihi taraf signifikansi sebesar 0.05 maka Ho diterima dan Ha ditolak, sedangkan jika p atau Asymp. Sig. (2-tailed) kurang dari taraf signifikansi sebesar 0.05 maka Ho Rank Test 
di atas, dapat diketahui bahwa tidak terdapat siswa yang mengalami penurunan nilai ketika pretest dan posttest, tetapi semua siswa mengalami kenaikan nilai setelah diberikan perlakuan menggunakan metode Think Talk Write (TTW) dengan peringkat rata- rata sebesar (Mean Rank) 4.5 dan dengan Sum of Ranks (jumlah peringkat rata-rata) sebesar 36. N dari data tersebut adalah sebanyak 8 orang siswa tunarungu kelas XI.

Berikut adalah perhitungan menggunakan Wilcoxon Sign Rank Test yang disajikan dalam bentuk tabel 5 .

Tabel 5 Nilai Wilcoxon Sign Rank Test

\begin{tabular}{|c|c|}
\hline Test Statisticsa & Postest - Pretest \\
\hline Z & $-2.533^{b}$ \\
\hline Asymp. Sig. (2-tailed) & .011 \\
\hline $\begin{array}{l}\text { a. Wilcoxon Signed Ranks Test } \\
\text { b. Based on negative ranks. }\end{array}$ & \\
\hline
\end{tabular}

Dapat diketahui bahwa diperoleh $\mathrm{Z}$ hitung $=-2.533$ dan dengan nilai Asymp. Sig. (2-tailed) atau $\mathrm{p}=$ 0.011 , selanjutnya dilakukan pembandingan dengan taraf signifikansi yang telah ditetapkan yaitu $\alpha=0.05$. Dalam tabel statistik Wilcoxon Sign Rank Test tersebut memuat mengenai pengaruh metode TTW terhadap kemampuan pemecahan masalah anak tunarungu pada saat sebelum maupun sesudah diberikan perlakuan yang meliputi jumlah keseluruhan data, mean, jumlah rata-rata dan standar deviasi. Berikut adalah perbandingan hasil nilai Asymp. Sig. (2-tailed) atau p dengan taraf signifikansi $\alpha=0.05$, yang disajikan ada tabel 6.

Tabel 6 Perbandingan Hasil Nilai Asymp. Sig. (2-tailed)

\begin{tabular}{|c|c|}
\hline Asymp. Sig. (2-tailed) & $\alpha$ \\
\hline $0.011<0.05$ \\
\hline
\end{tabular}

Dapat diketahui bahwa nilai Asymp. Sig. (2-tailed) adalah 0.011 dan lebih kecil dari taraf signifikansi yang telah ditetakan yaitu $\alpha=0.05$, berdasarkan ketentuan yang telah ditetapkan, jika $p$ atau Asymp. Sig. (2tailed) kurang dari taraf signifikansi sebesar 0.05 maka Ho ditolak dan Ha diterima. 


\section{KESIMPULAN}

Berdasarkan analisis yang telah dilakukan menggunakan Wilcoxon Sign Rank Test terjadi adanya peningkatan yang signifikan pada rata-rata hasil pretest dan posttest. Hasil dari rata-rata nilai siswa sebelum diberikan perlakuan menggunakan metode TTW adalah 47.125, kemudian setelah diberikan perlakuan menggunakan metode TTW, rata-rata nilai posttest siswa meningkat menjadi 67.75

Selanjutnya dilakukan pengujian signifikansi menggunakan analisisis Sign Rank terhadap hasil pretest dan posttest menggunakan bantuan aplikasi SPSS versi 25. Dari hasil pengujian tersebut, maka didapat hasil perhitungan $\mathrm{Z}$ hitung $=-2.533$ dan dengan nilai Asymp. Sig. (2tailed) $=0.011$ dengan taraf signifikansi $\alpha=0.05$. Hasil nilai pretest siswa yang tergolong rendah disebabkan karena merupakan bagian dari kondisi kemampuan awal siswa dalam mengerjakan soal pemecahan masalah matematika dan belum diberikan perlakuan menggunakan metode TTW.

Penelitian dan analisis yang dilakukan oleh peneliti metode TTW memiliki pengaruh dalam pembelajaran, hal tersebut dapat dilihat dari tahapan metode TTW yaitu dalam proses Think (berpikir) membantu siswa dalam mengembangkan konsep matematika dan berpikir kritis, pada proses Talk (berbicara/mengungkapkan) dapat meningkatkan komunikasi matematik dan membuat siswa lebih aktif dalam kegiatan pembelajaran. Selanjutnya pada proses Write (menulis) dapat membantu siswa lebih memahami materi ajar karena dituliskan kembali dalam tulisan setelah sebelumnya diungkapkan menggunakan kata-kata dan siswa menulis sesuai dengan apa yang telah dipahami. Dengan demikian, dapat disimpulkan bahwa penggunaan metode Think Talk Write (TTW) berpengaruh terhadap kemampuan pemecahan masalah matematika anak tunarungu kelas XI di SLB Negeri Surakarta Tahun Ajaran 2019/2020.

Hasil penelitian dapat disimpulkan bahwa metode TTW berpengaruh terhadap kemampuan pemecahan masalah matematika anak tunarungu kelas XI SLB Negeri Surakarta tahun ajaran 2019/2020. Ditunjukkan dengan peningkatan nilai pretest dan posttest, nilai siswa ketika pretest tergolong rendah, kemudian setelah diberikan perlakuan menggunakan metode TTW, nilai posttest mengalami kenaikan. Pemberian perlakuan menggunakan metode TTW membuat siswa menjadi lebih aktif dan komunikatif. Selain itu, juga terdapat hambatan dalam penelitian ini yaitu tidak semua siswa mau dengan kelompok yang telah dipilihkan, sehingga peneliti sedikit membutuhkan waktu agar sejalan dengan kenyamanan belajar siswa. 


\section{DAFTAR PUSTAKA}

Amir, M.Z. (2015). Pengaruh Pembelajaran Kontekstual Terhadap Kemampuan Pemecahan Masalah Matematika Siswa Sekolah Dasar . Prosiding Seminar Nasional Pendidikan, hlm. 34-42. Sidoarjo: FKIP Universitas Muhammadiyah Sidoarjo.

Dewayani.D.A. (2016). Model Pembelajaran Think Talk Write (TTW) Terhadap Hasil Belajar Pemecahan Soal Cerita Bilangan Bulat Matematika Siswa Tunarungu. Jurnal Pendidikan Khusus, 1-6. Diperoleh 16 September 2019, dari http://jurnalmahasiswa.unesa.ac.id

Haenudin. (2013). Pendidikan Anak Berkebutuhan Khusus Tunarungu. Bandung : PT Luxima Metro Media

Huda, M. (2014). Model - Model Pengajaran dan Pembelajaran. Yogyakarta: Pustaka Belajar

Irawan.I.P.E., Suharta.I.G.P., Suparta.I.N.(2016). Faktor-faktor Yang Mempengaruhi Kemampuan Pemecahan MasalahMatematika: Pengetahuan Awal, Apresiasi Matematika, dan Kecerdasan Logis Matematis . Prosiding Seminar Nasional MIPA, hlm. 69-73. Singaraja: Prodi Pendidikan Matematika Program Pasca Sarjana, Universitas Pendidikan.

Nissa, I.C. (2015) . Pemecahan Masalah Matematika (Teori dan Contoh Praktek.) Mataram : Duta Pustaka Ilmu

Shoimin, Aris (2014). 68 Model Pembelajaran Inovatif dalam Kurikulum 2013. Yogyakarta : Ar-Ruzz Media

Sibuea, M.F.L. (2017). Implementasi model pembelajaran kooperatif tipe think talk write (TTW) sebagai upaya meningkatkan hasil belajar siswa. Journal of Mathematics Education and Science, 2 (2), 44- 45. Diperoleh 2 April

2019, dari https://jurnal.uisu.ac.id

Syahlan. (2017). Sepuluh Strategi dalam Pemecahan Masalah Matematika. Indonesian Digital Journal of Mathematics and Education.4(6), 358-369. Diperoleh 11 November 2019, dari http://idealmathedu.p4tkmatematika.org 